\title{
Control of cashew black mould by acibenzolar-S-methyl
}

\author{
Francisco M.P. Viana ${ }^{1 *}$, Joilson S. Lima ${ }^{2}$, Francisco A. Lima ${ }^{3}$ \& José Emilson Cardoso ${ }^{1}$ \\ ${ }^{1}$ Embrapa Agroindústria Tropical, Rua Sara Mesquita, 2270, 60511-110, Fortaleza, CE, Brazil; ${ }^{2}$ Departamento de Fitotecnia, \\ Universidade Federal do Ceará, Av. Mister Hull, s/n - Campus do Pici, 60356-000, Fortaleza, CE, Brazil; ${ }^{3}$ Departamento \\ de Engenharia Agrícola, Universidade Federal do Ceará, Av. Mister Hull, s/n - Campus do Pici, 60356-000, Fortaleza, CE, \\ Brazil
}

Author for correspondence: Francisco M.P. Viana, e-mail: fmpviana@cnpat.embrapa.br

\begin{abstract}
Black mould is one of the most important foliar diseases of dwarf cashew plants in coastal zone of northeastern Brazil. In order to develop a reliable method to control this disease, a field experiment was conducted in the 2008/2009 season to evaluate the effect of acibenzolar-S-methyl (ASM) on disease severity at three different intervals with two, four and six times of applications per season. Copper oxychloride was used every 15 days as a control fungicide. An adult cashew orchard of the susceptible clonal variety CP-76 was used. Black mould severity was estimated by monthly evaluations by scoring each plant according to a 0 to 4 severity scale. Disease severity indexes per plot and per month were used for statistical analyses to compare treatment effects. ASM significantly reduced black mould in the epidemic season tested. Two applications of ASM at 30 days interval were enough to reduce disease in cashew plants.
\end{abstract}

Key words: Anacardium occidentale, Pilgeriella anacardii, ASM, SAR.

Black mould, caused by the obligate parasite fungus Pilgeriella anacardii Von Arx and Muller, is one of the most important disease of cashew (Anacardium occidentale) in coastal zones of northeastern Brazil. Severe epidemics of this disease have occurred in recent years as a result of expanding area cultivated with the susceptible clonal variety CP-76 (Cardoso et al., 1999, 2000; Freire et al., 2002). The pathogen grows profusely on the lower surface of leaves showing a black layer of mycelium and fruiting bodies which accounts for the common name of the disease (Freire et al., 2002). Fungus penetration occurs through stomata which become blocked to gas exchanges, thus reducing leaf and shoot growth. Initial symptoms are chlorotic spots on the upper surface of leaves (Cardoso et al., 1999). Later, on the lower surface the pathogen forms dark colonies giving a velvet-like appearance. Black mould can only be observed in old, mature leaves, one reason why it used to be referred to as an unimportant disease. However, disease epidemics have noticed to imposed great damage to the crop in this particular region, as nut yield losses of 33\% have been demonstrated (Cardoso et al., 2000).

Experimentally, black mould control has been achieved either by spraying chemical fungicides or resistant clones (Cardoso et al., 1999; Freire, 1991, 2002). An additional possible control measure is the use of induced resistance.

The use of biological and chemical agents to promote systemic acquired resistance (SAR) have been increasing very rapidly as an alternative for controlling plant diseases (Lyon and Newton, 1997; Katz et al., 1998; Valdebenito-
Sanhueza, 2000). Acibenzolar-S-methyl (ASM) (1,2,3benzothiadiazole-7-thiocarboxylic acid S-methyl ester) is a photostable functional molecule analogue of salicylic acid which affects biochemical and physiologic processes in plants to induce SAR to a wide range of plant pathogens with low toxic effect to host plant, therefore it shows a high potential for disease control (Görlach et al., 1996). ASM may enhance activity of glucanases and peroxidases (Stadnik and Buchenauer, 2000) and lipoxygenases (Görlach et al., 1993), which contribute to increase the levels of phenolic compounds and phenylalanine ammonia-lyase activity, and it is thought to be translocated systemically in plants (Oostendorp et al., 2001). Efficient disease control by using ASM have been achieved under tropical conditions for cocoa (Cavalcanti and Resende, 2005; Silva et al., 2008), coffee (Marchi et al., 2002) and melon (Sales Junior et al., 2007).

The evidence concerning the use of inducers of resistance to cashew diseases is completely lacking and even limited reports have been published on the effects of number and frequency of ASM applications on perennial woody tropical fruit plants. Thus, the objective of this study was to determine if ASM is able to induce cashew resistance against black mould as a possible mean to control this disease.

The experiment was carried out in the 2008/2009 season at the Experimental Research Station of Embrapa, in Pacajus, Ceará, Brazil. Cashew plants of the susceptible clone variety (CP 76), transplanted in March, 2004, were used. Thirty-days before settling out the experiment, all 
plants were fertilized, heavily pruned and completely defoliated both to stimulate shooting and to standardize disease onset.

Experimental treatments consisted of ASM (Bion ${ }^{\circledR}$ WG 50; Syngenta Proteção de Cultivos Ltda. São Paulo, $\mathrm{SP}$, Brazil) at $0.03 \mathrm{~g} \mathrm{~L}^{-1}$, copper oxychloride (Recop ${ }^{\circledR} \mathrm{WP}$ 84; Atar do Brazil Defensivos Agrícolas Ltda. Resende, $\mathrm{RJ}$, Brazil) at $3 \mathrm{~g} \mathrm{~L}^{-1}$ concentration and water spray as an additional control.

Cashew foliage was sprayed over using a 20 -L hand-held sprayer with either ASM or copper oxychloride accordingly to different intervals and number of spraying. ASM was suspended in water before use and applied either by 21 or 30 days intervals and repeated two, four and six times, beginning in February, 2008. Copper oxychloride was applied twelve times at every 15 days intervals. Both products were applied with $0.01 \%$ Tween 20 (Polyoxyethylene sorbitan monolaurate) (Mapric ${ }^{\circledR}$, São Paulo, SP, Brazil) as a dispersant. Each spray volume consisted of $0.5 \mathrm{~L}$ of aqueous solution per plant. The experiment was carried out in a completely randomized block design with three replications. Each plot consisted of four trees spaced 7 by 7 $\mathrm{m}$ with a double plant row as borders.

Black mould was evaluated monthly throughout the epidemic cycle (from March 2008 to January, 2009) by scoring each plant as $0=$ plants without visible symptoms; $1=$ lesions covering up to $2 \%$ of leaf area; $2=$ lesions covering up to $5 \%$ of leaf area; $3=$ coalescent lesions covering 5 to $25 \%$ of leaf area; and $4=$ coalescent lesions covering more than $25 \%$ of leaf area (Cardoso et al., 1999). Data were taken by looking at each plant canopy from all the four cardinal points. All plants in the plot were evaluated and data was used to calculate black mould severity index (BMSI), according to the formula: BMSI
$=\Sigma \mathrm{x} / \mathrm{n}(\mathrm{x}=$ score by plant, $\mathrm{n}=$ number of observed plants $)$. Data from BMSI was used for statistical analysis after transformation by $\sqrt{x+0.5}$. Eleven disease evaluations altogether were accomplished from March, 2008 to January, 2009.

Area under disease progress curve (AUDPC) was calculated and used for the analysis of variance using the statistical package Sisvar (5.3 version, Universidade Federal de Lavras, Lavras, MG, Brazil). Comparisons among means were made using Tukey's multiple range test $(P \leq 0.05)$. In addition to the mean comparisons, treatments were partitioned into orthogonal contrasts in order to compare specific treatments such as ASM versus fungicide, ASM versus control plants, ASM 2 times versus 4 times, ASM 2 times versus 6 times, ASM 4 times versus 6 times, ASM every 21 days versus every 30 days, and fungicide application versus all the others treatments.

Black mould incidence throughout evaluated season was very high as shown by incidence on untreated plants. Almost all treatments with ASM lowered the disease score significantly $(P<0.005)$ compared with the water treated control (Figure 1). ASM effectively reduced black mould severity throughout the epidemic season. Copper oxychloride was the best treatment to reduce black mould although it did not differ significantly from ASM with six and four applications and only with two at monthly intervals.

The effect of ASM, copper oxychloride and untreated control on black mould progress throughout the entire year showed less amount of disease in treated epidemic than in the untreated one and higher disease incidence was observed in June and July (Figure 2).

There was a significant linear decrease $(P<0.05)$ in the AUDPC as the number of applications increased (data not shown).

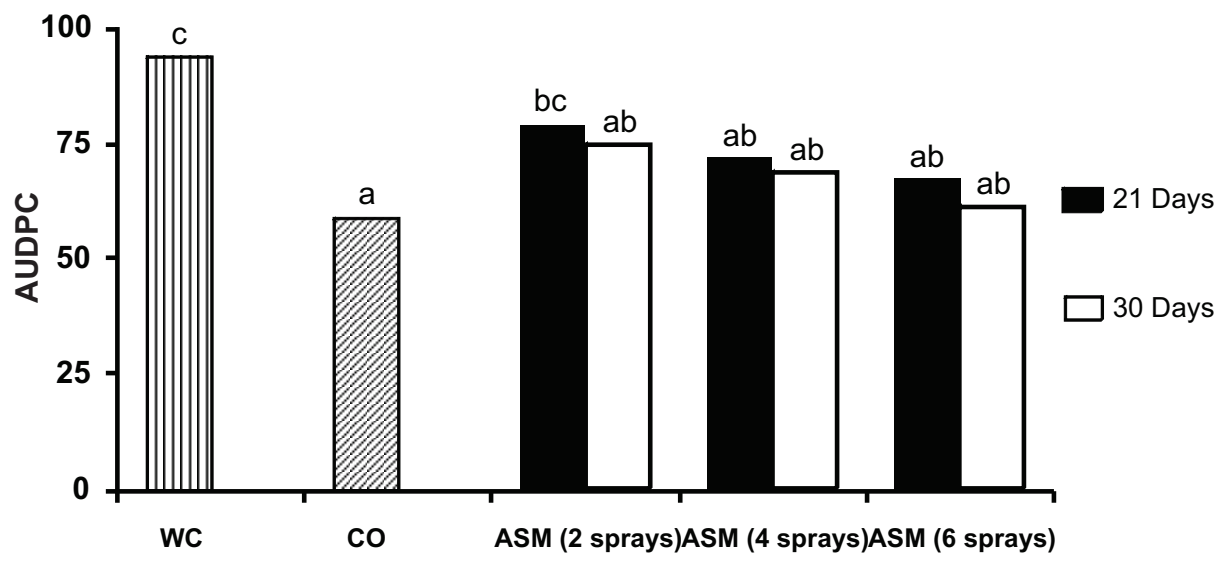

FIGURE 1 - Area under disease progress curve (AUDPC) for cashew plants treated with acibenzolar-S-methyl (ASM) at two, four and six times at 21 or 30 days intervals and copper oxychloride $(\mathrm{CO})$ applied twelve times at 15 days intervals in comparison to the water control treatment (WC). Black mould was scored on a scale from a 0 to 4 based on leaf lesions every month throughout the raining season. Numbers are means of three plots (four plants each) in the $2008 / 2009$ season. Different letters indicate significant difference $(P<0.05)$ according to Tukey's multiple range test. 


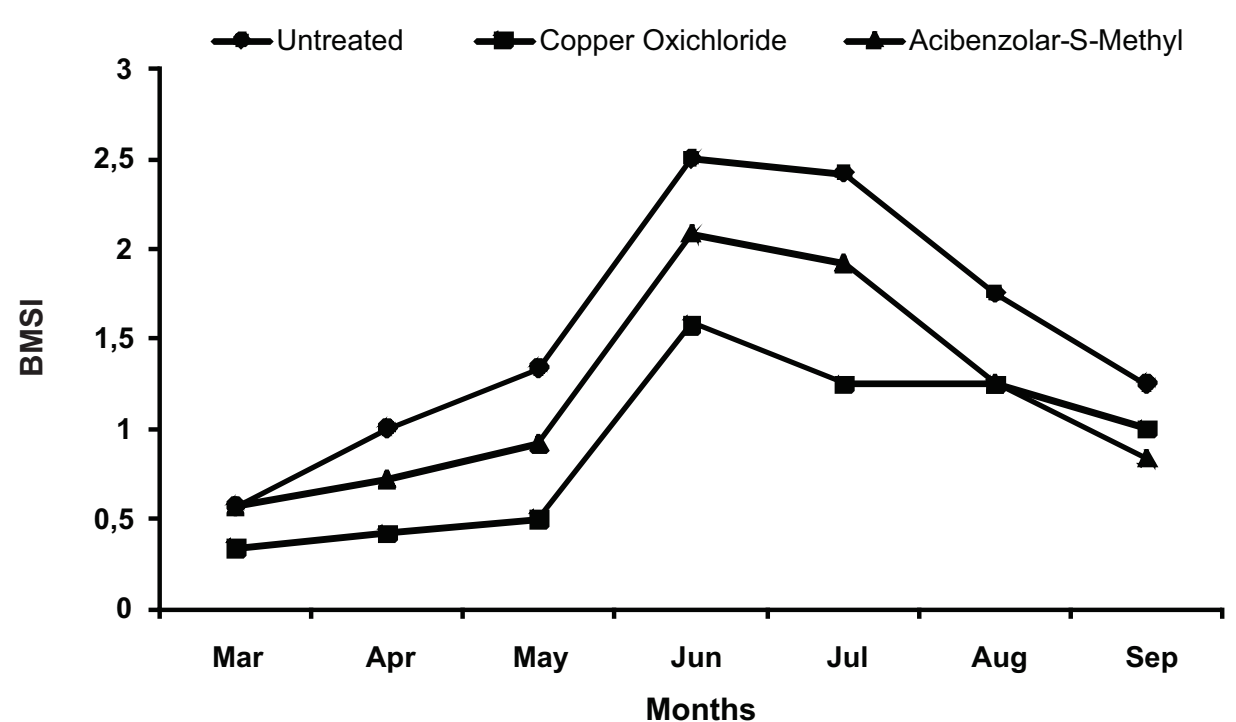

FIGURE 2 - Black mould severity index (BMSI) on leaves of cashew plants sprayed with acibenzolar-S-methyl, copper oxiychloride, and water.

Orthogonal contrast analyses were done in order determine the independent response involving pairs of factors, whether number and interval of ASM applications, copper oxychloride, and water control. Such analyses showed that all ASM contrasts were not significantly different regardless of the number and frequency (Table 1). All source of variation in the orthogonal contrasts, which included number and interval of ASM application, were not significantly different. Copper oxychloride showed the best effect on reducing black mould in contrast to all others treatments.

Black mould incidence was always higher throughout the experiment, reaching the highest severity rate during the raining season. These findings support the data from Cardoso et al. (2000).

Copper oxychloride was included in the experiment as a control presently recommended to cashew growers to reduce black mould intensity. The effective control of cashew black mould by copper oxychloride has been showed (Freire, 1991); thus data from the present study confirms those findings. ASM also effectively controlled the disease as compared with untreated plots. Therefore, ASM can be used as a defense activator to induce cashew resistance to black mould. In most of treated plants with ASM, black mould symptoms were reduced and the effect was enhanced with increase in the number of applications. Obviously, the different mechanism of action between the fungicide and ASM make their effects difficult to compare. However, considering that it took 12 applications of fungicide to efficiently control the disease, the use of ASM as an inducer of resistance seem to be potentially of greater practical advantageous than the fungicide due to the reduced labor and machinery for application procedures.

The reducing impact of copper oxychloride and ASM on disease progress throughout the season can be observed on Figure 1, where copper oxychloride showed a greater effect than ASM. As a rapidly spreading ectoparasite, black mould fungus promptly responds to protective compounds such as copper- and sulfur-based fungicides, which acts readily on the site of fungus penetration. Nevertheless, the application of chemical compounds to induce disease resistance is based in some signal transduction pathways, which induce genes to produce particular enzymes catalyzing biosynthetic reactions to form defense compounds such as polyphenols, alkaloids or pathogenesis-related proteins, thus these processes takes time to be activated. In apple, for example, application of ASM increased resistance to fire-blight when time between application and inoculation was increased from 2 to 10 days (Brisset et al., 2000). The linear increased resistance to black mould by increased number of ASM applications is an indication that the metabolism for acquiring resistance in cashew plants, like others perennial woody plants is time dependent, differently from a protective fungicide.

Orthogonal contrasts analyses depicted a very clear effect of fungicide as contrast with ASM, although the later showed a significant different effect with control treatment. These data is an indication that ASM has some sort of resistance inducing effect on black mould, though not as high as the protective effect of the tested fungicide. All combinations of number and spraying intervals of ASM did not differ when analyzed by contrasts (Table 1) but only when applied twice at 21 days-interval, it did not differ from control treatment (Figure 1).

This is the first study on the use of ASM to induce cashew resistance to black mould. This may open a new approach to effectively control cashew diseases other than black mould. However, additional research is needed before ASM could be recommended to be applied in cashew orchards such as timing of spray and interaction with other chemicals or cultural practices. 
Control of cashew black mould by acibenzolar-S-methyl

TABLE 1 - Pairwise comparisons for 3-year-average black mould severity index via analysis of orthogonal contrasts

\begin{tabular}{lcccc}
\hline \hline Contrasts $^{\text {a }}$ & Estimated differences & Standard errors $^{*} \boldsymbol{P}_{\text {values }}{ }^{\mathbf{t}}$ & 0.066 & 3.741 \\
ASM vs. Copper & 0.25 & 0.002 & -5.192 \\
ASM vs. Control & -0.34 & 0.066 & 0.061 & 0.619 \\
2ASM vs. 4ASM & 0.04 & 0.061 & 1.546 \\
2ASM vs. 6ASM & 0.09 & 0.061 & 0.928 \\
4ASM vs. 6ASM & 0.06 & 0.144 & 0.369 \\
ASM30 vs. 21ASM & 0.07 & 0.049 & 0.179 \\
\hline
\end{tabular}

${ }^{\mathrm{a}} \mathrm{ASM}=$ acibenzolar-S-methyl; copper $=$ copper oxychloride; 2,4 and $6=$ number of applications; 21 and $30=$ days intervals of applications ${ }^{\mathrm{b}}$ Nominal significance levels of $t$-test.

\section{ACKNOWLEDGMENTS}

The authors are grateful to the Conselho Nacional de Ciência e Tecnologia - CNPq for the financial support.

\section{REFERENCES}

Brisset MN, Cesbron S, Thomson SV, Paulin JP(2000)AcibenzolarS-methyl induces the accumulation of defense-related enzymes in apple and protects from fire blight. European Journal of Plant Patholology 106:529-536.

Cardoso JE, Cavalcanti JJV, Cavalcante MJB, Aragão ML, Felipe EM (1999) Genetic resistance of dwarf cashew (Anacardium occidentale L.) to anthracnose, black mould, and angular leaf spot. Crop Protection 18:23-27.

Cardoso JE, Felipe EM, Cavalcante MJB, Freire FCO, Cavalcanti JJV (2000) Precipitação pluvial e progresso da antracnose e do mofo-preto-do-cajueiro (Anacardium occidentale L.). Summa Phytopathologica 26:413-416.

Cavalcanti LS, Resende MLV (2005) Efeito da época de aplicação e dosagem de acibenzolar-S-metil na indução de resistência à murcha-de-verticilium em cacaueiro. Fitopatologia Brasileira 30:67-71.

Freire FCO, Cardoso JE, Santos AA, Viana FMP (2002) Diseases of cashew (Anacardium occidentale L.) in Brazil. Crop Protection 21:489-494.

Freire FCO (1991) Controle químico do mofo preto (Diploidium anacardiacearum Bat. \& Cav.). Revista Brasileira de Fruticultura 13:53-55.

Görlach J, Schmid J, Amrhein N (1993) Differential expression of tomato (Lycopersicon esculentum L.) genes encoding shikimate pathway isoenzymes. II. Chorismate synthase. Plant Molecular Biology 23:707-716.
Görlach JL, Volrath S, Knauf-Beiter G, Hengy G, Beckhove U, Kogel K H, Oostendorp M, Staub E, Kessmann H, Ryals J (1996) Benzothiadiazole, a novel class of inducers of systemic acquired resistance, activates gene expression and disease resistance in wheat. Plant Cell 8:629-643.

Katz VA, Thulke OU, Conrath U (1998) A benzothiadiazole primes parsley cells for augmented elicitation of responses. Plant Physiology 117:1333-1339.

Lyon GD, Newton AC (1997) Do resistance elicitors offer new opportunities in integrated disease control strategies? Plant Pathology 46:636-641.

Marchi CE, Borges MF, Resende MLV (2002) Proteção induzida por benzotiadiazole contra a ferrugem-alaranjada (Hemileia vastatrix) em cafeeiro. Ciência e Agrotecnologia 26:1103-1106.

Oostendorp M, Kunz W, Dietrich B, Staub T (2001) Induced disease resistance in plants by chemicals. European Journal of Plant Patholology 107:19-28.

Sales Junior R, Pontes Filho FST, Nunes GHS, Torres GRC (2007) Eficiência de acibenzolar-S-methyl e oxicloreto de cobre no controle de Acidivorax avenae subsp. citrullii, agente causal da "mancha-aquosa" no meloeiro. Revista de Biologia e Ciências da Terra 7:66-71

Silva ILSS, Resende MLV, Ribeiro Junior PM, Costa JCB, Camilo FR, Batista JC, Salgado SML (2008) Efeito de nutrientes combinados com indutores de resistência na proteção contra a vassoura-de-bruxa no cacaueiro. Ciência e Agrotecnologia 32:6167.

Stadnik MJ, Buchenauer H (2000) Inhibition of phenylalanine ammonia-lyase suppresses the resistance induced by benzothiadiazole in wheat to Blumeria graminis f. sp. tritici. Physiological and Molecular Plant Pathology 57:25-34.

Valdebenito-Sanhueza RM (2000) Leveduras para o biocontrole de fitopatógenos. In: Melo IS, Azevedo JL (Eds.) Controle biológico. Jaguariúna SP. Embrapa Meio Ambiente. pp. 41-55. 